JAREMA DROZDOWICZ

ORCID 0000-0003-1060-6324

Uniwersytet im. Adama Mickiewicza

$w$ Poznaniu

\title{
POST-EDUKACJA I ANTYINTELEKTUALIZM JAKO ZJAWISKA KULTUROWE
}

\begin{abstract}
Aвstract. Drozdowicz Jarema, Post-edukacja i antyintelektualizm jako zjawiska kulturowe [Post-education and Anti-intellectualism as Cultural Phenomena]. Studia Edukacyjne nr 54, 2019, Poznań 2019, pp. 71-81. Adam Mickiewicz University Press. ISSN 1233-6688. DOI: 10.14746/se.2019.54.5

This paper makes the attempt to highlight the role played in contemporary education by the notion of post-truth and the influence played in that matter by anti-intellectual tendencies. This issue seems to be imperious in the face of transformation tendencies of the schooling systems and the influence exerted by the world of politics in that context. This text reconstructs the most important aspects of the anti-intellectual stance, treating it as a specific phenomenon of a cultural nature. Furthermore, the emerging issue of post-education is addressed as it accompanies the anti-intellectual tendencies and strengthens their impact on the schooling level. Both issues are in a clear cause-and-effect relation to the phenomenon of post-truth.
\end{abstract}

Key words: post-truth, education, schooling, post-education, educational politics

Szkoła jest zazwyczaj miejscem, w którym uczniowie po raz pierwszy w swym młodym życiu spotykają się z postawami obywatelskimi, zasadami zorganizowanej współpracy, czy też ideą bezinteresownego zaangażowania na rzecz dobra wspólnoty. Czy będzie to wspólnota rówieśnicza, uczniowska, czy też szerzej pojmowana partycypacja społeczna - granice tej postaci zbiorowej współodpowiedzialności za formowanie rzeczywistości wyznaczane są dzięki bezpośredniemu doświadczeniu życia z innymi, takim jak chociażby doświadczenie szkolne. Jakkolwiek jednak nie rozpatrywać szkolnego doświadczenia jako pierwszej lekcji odpowiedzialności, to samo doświadczenie życiowe dostarcza nam także nauki zgoła odmiennej. Mówi ona nam niekiedy, iż podejmowanie wysiłku, odpowiedzialność za słowa i czyny, czy też trwanie $w$ prawdzie nie zawsze jest opłacalną strategią $w$ bieżącej kondycji współczesności. Z punktu widzenia partykularnego interesu częściej wycho- 
dzimy lepiej naginając fakty, formułując radykalne twierdzenia na podstawie niesprawdzonych informacji lub po prostu wyrażając zdania, które nie tylko rozmijają się z prawdą, lecz są świadomym i cynicznie stosowanym kłamstwem. W miejsce prawdy wdziera się bowiem pojęcie post-prawdy, coraz częściej obecnie stosowany eufemizm, odnoszący się do szerokiego spektrum rozmaitych form kłamstwa, niedomówien i półprawd przepełnionych fałszem. Zagarnia ono pole zarezerwowane zwyczajowo dla antytezy celu, do jakiego dąży nauka, kształcenie, czy też proces intelektualnego samodoskonalenia się. Celem tym jest bowiem wyeksponowanie na drodze procesu analitycznego twierdzeń mówiących nam jak świat jest skonstruowany oraz jakimi drogami możemy nieśmiało odsłonić część jego tajemnic. Upowszechnianie się i poszerzająca się skala użycia tego zwrotu retorycznego przyczynia się zatem do dezintegracji nie tylko nadrzędnej roli prawdy naukowej, ale i samej nauki w jej najbardziej fundamentalnej postaci. Celem zaś niniejszego wywodu jest ukazanie, jak zjawisko post-prawdy oraz wszelkie związane z nim fenomeny natury społeczno-kulturowej odciskają obecnie swoje wyraźne piętno w sferze edukacji i szkolnictwa.

Przypomnijmy, że pojęcie post-prawdy zyskało w roku 2016 status słowa roku według twórców słownika oxfordzkiego i niemalże natychmiast znalazło się na ustach wszystkich, którym bliska jest troska o zachowanie chociażby rudymentarnych standardów w debatach publicznych ${ }^{1}$. Post-prawda pojawiła się również w przestrzeni dyskursu publicznego, dzięki medialnemu zamieszaniu wokół fenomenów o narastającym dziś znaczeniu dla ukierunkowania tegoż dyskursu, takich jak populizm polityczny i wypływająca z niego retoryka populistyczna. Samo pojęcie było jednak znane wcześniej. Pojawiło się już w roku 1992, kiedy zostało użyte przez Steve'a Tesicha $\mathrm{w}$ artykule zamieszczonym $\mathrm{w}$ amerykańskim czasopiśmie „The Nation", w którym autor określa post-prawdę jako sposób, w jaki Ameryka przeistoczyła się w społeczeństwo, w którym prawda stała się politycznie nieistotna ${ }^{2}$. Z kolei Ralph Keyes utrzymuje, że problem rozprzestrzeniania się post-prawdy dotknął nad wyraz wiele obszarów życia publicznego, nie oszczędzając przy tym również sfery akademickiej ${ }^{3}$. Dla Keyesa uniwersytety (przynajmniej te amerykańskie) charakteryzuje duży stopień zmienności standardów etycznych. Pewne praktyki akademickie są uznawane za dopuszczalne, tolerowane, mniej lub bardziej otwarcie wspierane przez władze uczelni. Ich etycznie wątpliwa natura może niemniej budzić szereg kon-

${ }^{1}$ A. Gilchrist, Post-truth: an outline review of the issues and what is being done to combat it, Ibersid, 2018, 12-2, s. 13-24.

2 S. Tesich, The Government of Lies, The Nation, 1992, 254, 1.

${ }^{3}$ R. Keyes, The Post-Truth Era: Dishonesty and Deception in Contemporary Life, New York 2004, s. 97. 
trowersji, stąd Keyes wyraża przekonanie, że oszustwa są wpisane w życie i praktykę uniwersytecką oraz procesy wytwarzania wiedzy naukowej ${ }^{4}$. Jak sam uważa, post-prawda w akademickim uniwersum nie jest jednak konsekwencją niechlujnie przeprowadzanych badań czy luźnych standardów metodologicznych zezwalających na dość umownie osiągane wyniki. Jest natomiast produktem zbliżenia nauki i polityki - tej w skali mikro uprawianej na wydziałach i kampusach, jak też tej makropolitycznych sił regulujących szkolnictwo wyższe i badania naukowe. Przykładem takiego zafałszowania faktów ze względów politycznych jest dla Keyesa aktywność postkolonialnego teoretyka Edwarda Saida, który ze względu na swe zaangażowanie polityczne w kwestii konfliktu bliskowschodniego zmanipulował historie swoich dokonań i związków z Palestyną ${ }^{5}$.

Powyższe tendencje można uznać po części za efekt oddziaływania polityki populistycznej, zachęcającej do poluźnienia niegdyś nienaruszalnych standardów. Problematyka nowej postaci, jaką przybiera obecnie populizm polityczny, stanowi w tym kontekście ważny element debaty na temat jakości współczesnych demokracji zachodnich oraz niedalekiej przyszłości systemów opartych na tradycyjnie pojmowanej demokracji parlamentarnej. Dostrzegają ten związek między innymi Ewan Speed oraz Russell Mannion, którzy twierdzą, iż terminem post-prawdy lub fake newsem możemy określić każdą szybko postępującą dziś transformację treści dyskursu populistycznego ${ }^{6}$. Daje takie postawienie sprawy bardzo szerokie ujęcie postaci, jaką post-prawda może przybierać w rejestrze polityki. Jednocześnie też wskazuje ono na dynamikę, jaką cechuje się ten wyłaniający się nadal termin w obszarze nowych antydemokratycznych ruchów społecznych i ich rosnącej popularności nie tylko w świecie zachodnim. Maciej Gdula nazywając ten dający się wyraźnie zauważyć także w Polsce neokonserwatywny zwrot nowym autorytaryzmem, pokazuje, jak dalece odbiega stan współczesnej polityki od celów i nadziei, które świat wyznaczył sobie po zakończeniu Zimnej Wojny, a jeszcze wcześniej po traumie Holokaustu ${ }^{7}$ Podkreślić zatem należy, że polityczny aspekt problemu post-prawdy jest nie do przecenienia w obliczu erozji instytucji państwa i jego prerogatywów, modelu społeczeństwa otwartego, czy niekiedy także nawet idei praw człowieka. Skłania tym samym bieżący stan rzeczy do zastanowienia się nad tym, jak ujawniające się we współczesnej rzeczywistości problemy społeczne i kulturowe wpływają na transformacje dokonu-

\footnotetext{
4 Tamże, s. 99.

5 Tamże, s. 101.

${ }^{6}$ E. Speed, R. Mannion, The Rise of Post-truth Populism in Pluralist Liberal Democracies: Challenges for Health Policy, International Journal Health Policy Managment, 2017, 6(5), s. $249-251$.

7 M. Gdula, Dobra zmiana w Miastku. Neoautorytaryzm w polskiej polityce z perspektywy małego miasta, Warszawa 2017.
} 
jące się nie tylko w obszarze polityki, lecz także innych, aczkolwiek związanych z nią sfer życia.

Do jednej z tego typu sfer, w których formowane są postawy i predyspozycje do obywatelskiego uczestnictwa $w$ demokracji, przynależą, jak już zaznaczyłem na początku, szkoła oraz wszelkie systemy edukacji. Rozwiązania organizacyjne regulujące szkolną codzienność, podstawy legislacyjne funkcjonowania instytucji edukacyjnych i realizowane w nich programy nauczania ukazują w dużej mierze, jak owo nauczanie odpowiedzialności za słowa i czyny rozchodzi się nierzadko z jej praktykowaniem w rzeczywistości społecznej. Efekt edukacyjny, jaki z natury rzeczy winien być produktem procesu kształcenia, jest bowiem coraz częściej wyrażany poprzez antyintelektualny i antydemokratyczny sentyment, którego długofalowe konsekwencje społeczno-kulturowe mogą wpłynąć na kierunek zmian, tak na poziomie lokalnej i narodowej polityki edukacyjnej, jak i bardziej globalnych tendencji w tym zakresie. To niepokojące zjawisko odejścia od edukacyjnych ideałów ma swoje podłoże osadzone w zdeterminowanym kulturowo zjawisku, którego istotę określić możemy jako nowy zwrot antyintelektualny. Fenomen ten wiąże się także z dyskursami politycznymi i przez dyskursy te jest uwarunkowana również forma, jaką przybiera on w rozmaitych przestrzeniach lokalności. Zwrot antyintelektualny nie jest oczywiście zjawiskiem masowym, lecz dzięki radykalnemu charakterowi postulatów rozmaitych związanych z nim ruchów społecznych i szerokiemu wykorzystaniu przez te ruchy nowych mediów uwidacznia się jaskrawo w ogólnym zarysie debaty na temat stanu bieżącego i przyszłości edukacji. Czynniki wpływające na rozprzestrzenianie się antyintelektualnych postaw, postulatów i działań opartych na negacji faktów na rzecz subiektywnych przekonań, czerpią natomiast siłę swojego oddziaływania ze specyficznych stanów kulturowego zawieszenia idei racjonalności i etosu intelektualnego. Ten wieloaspektowy fenomen możemy rozpatrywać w jego globalnym wymiarze, aczkolwiek to jego silnie osadzone lokalnie warianty uzmysławiają nam, jak dalece wiąże się on z wymiarem kulturowym. Wytwarzany jest bowiem dzięki niemu specyficzny stan kultury post-prawdy, która przybiera na sile w szczególności w społeczeństwach, w których ponad fakty cenione są bardziej nieugruntowane opinie ${ }^{8}$.

Antyintelektualizm nie jest jednak zjawiskiem zupełnie nowym w sensie historycznym. Jego początki lokować możemy w dyskusjach na temat roli społecznej, jaką odgrywa nauka i uczeni toczonych w XVII wieku w obrębie teologii protestanckiej, w szczególności purytańskiej krytyki ówczesnych prób wprowadzenia świeckiej, a więc wyzbytej z religijnej dogmatyczności edukacji. Krytyka intelektualistów ze strony konserwatywnych i religijnie mo-

\footnotetext{
${ }^{8}$ J. Baginni, A Short History of Truth. Consolations ofr the Post-Truth World, London 2018.
} 
tywowanych zwolenników prymatu wiary nad rozumem zyskała sobie wówczas nie tylko rozgłos i akceptację ze strony kościelnych hierarchów, przez co także trwale wpisała się $\mathrm{w}$ rozwijany $\mathrm{w}$ wiekach kolejnych antynaukowy sentyment ${ }^{9}$. Takie opozycyjne postawienie wiary i nauki jest zresztą do dziś uznawane $\mathrm{w}$ popularnym przekonaniu za jedną z podstawowych antynomii regulujących uniwersum idei. Konsekwencje, jakie niesie ze sobą ustanowienie jej jako naturalnego i zrozumiałego samego przez się porządku w relacjach nauki i naukowej racjonalności ze światem, w którym nauka się porusza i który bada, fałszują jednakże znacząco charakter tego związku. Stanowi on bowiem złożony tak w sensie historycznym, jak i filozoficznym, problem natury światopoglądowej. Jak przypomina w tej materii Max Horkheimer:

z punktu widzenia historii filozofii swą pierwszą egzemplaryczną postać uzyskuje ono w połączeniu metodycznego wątpienia Kartezjusza z jego szczerym katolicyzmem ${ }^{10}$.

Jak widzimy zatem, próby przeciwstawienia intelektualnego przedsięwzięcia innym formom epistemologicznym nie opierają się na zrównaniu racjonalności z pojęciem nauki i postawienie jej naprzeciw introspektywnemu doświadczeniu oferowanemu między innymi przez religię, lecz bardziej na zespoleniu różnych dróg, poprzez które doświadczamy rzeczywistości w jeden zwarty system przekonań. Kluczowym problemem staje się zatem określenie podstaw, na jakich owe przekonania funkcjonują i skłaniają nas do podjęcia określonych działań. Czy będą to empiryczne fakty, czy jedynie pewne prowadzące do ich odkrycia przypuszczenia pozostaje w kwestii partykularnych wyborów dokonywanych $\mathrm{w}$ obrębie panujących $\mathrm{w}$ danym momencie warunków historycznych, społecznych i kulturowych.

Wracamy tym samym niezmiennie do problemu kulturowego ukontekstowienia tradycji antyintelektualnych. Jak udało się już ustalić, zjawisko negacji postawy intelektualnej dociekliwości i rygoru metody naukowej nie jest bezpośrednio zależne od dominacji postaw religijnych, choć pośrednio wiąże się z typową dla światopoglądu religijnego dogmatycznością wzorów myślenia. Czynniki takie jak kultura są jednak także same w sobie niejednoznacznym i skomplikowanym amalgamatem rozmaitych wzorów wyznaczających ramy, w których porusza się pojęcie prawdy. Połączenie tych dwóch obszarów, kultury i moralności, pozostaje zresztą w domenie analitycznych dociekań nie tylko filozofii, ale też wielu nauk społecznych. Przyglądając się bliżej socjokulturowym uwarunkowaniom antyintelektualizmu, możemy zauważyć, że fenomen ten przybrał na sile w kontekście określonym przez wydarzenia ostatnich dwóch dekad i będący ich efektem zwrot w światowej po-

\footnotetext{
${ }^{9}$ K.J. Worthen, The Pursuit of All Truth, Brigham Young University Speeches, 2017.

${ }^{10}$ M. Horkheimer, Społeczna funkcja filozofii, Warszawa 1987, s. 75.
} 
lityce. Prezydentura Donalda Trumpa w USA, niekończący się proces wyjścia Wielkiej Brytanii ze struktur Unii Europejskiej, czy kontrowersje wokół zmian klimatycznych - wszystkie te problemy łączy pewien specyficzny konsensus co do pęknięcia, jakie dokonało się rzekomo w sferze kulturowo definiowanych wartości i przewodnich dla zachodnich społeczeństw idei. U jej podstaw leżeć ma upowszechniający się relatywizm, przyczyniający się do korozji kardynalnych aksjologicznych podstaw zachodniego stylu życia. Jakkolwiek argument ten wydaje się dalece bezpodstawny pod względem merytorycznym, posiada on silny rezonans w sferze społecznej. Większość neokonserwatywnych ruchów politycznych powstałych na przestrzeni ostatnich lat w Europie lub Stanach Zjednoczonych przyjmuje, iż to świat tradycyjnych kulturowych wartości jest obiektem ataku ze strony rozmaitych frakcji i sił politycznych dążących do destabilizacji status quo i odwrócenia relacji władzy, w których to Zachód i jego wzory aksjologiczne wiodły prym. Idea ta, odzwierciedlona między innymi w wersji liberalnej przez Francisa Fukuyamę, łączy tak umiarkowane, jak i skrajne warianty reprezentacji powyższego światopoglądu. W efekcie otrzymujemy zjawisko nie tylko o szerokim spektrum swoich politycznych manifestacji, lecz także w gruncie rzeczy posiadające charakter ponadnarodowy i paradoksalnie także (zważywszy nacjonalistycznie zabarwioną często formułę antyintelektualizmu) - globalny.

Związek postaw i ruchów antyintelektualnych z problemem post-prawdy odnajduje swoje odzwierciedlenie w debatach skupionych wokół kwestii przyszłości kształcenia i szkolnictwa wyższego. Niechęć wyrażana wobec postulatu transmisji pewnych prawd naukowych w szkołach publicznych widoczna staje się już nie tylko w amerykańskich sporach odnośnie nauczania kreacjonizmu $\mathrm{w}$ miejsce teorii ewolucji, lecz jej manifestacje możemy również znaleźć w innych kontekstach lokalnych. Podobnie też w polskim przypadku warto zauważyć zbliżone próby podważenia pewnych racjonalnych przesłanek $\mathrm{w}$ modyfikacjach programu nauczania na poziomie szkół podstawowych i średnich. O ile jednak uwaga ta nie dotyczy na chwilę obecną nauk przyrodniczych, zdecydowanie tendencje te ujawniają się w obszarze nauk humanistycznych takich jak na przykład historia. Sytuacja ta rodzi pewien dysonans pedagogiczny, w którym określone narracje historyczne zostają zastąpione innymi i eliminują dane fakty historyczne jako zbędne w procesie kształtowania świadomości historycznej uczniów. W konsekwencji, następuje istotne zerwanie ciągłości nie tyleż w kwestii rekonstrukcji procesów dziejowych na podstawie rzetelnej analizy faktów, co w przestrzeni relacji i komunikacji niezbędnych w każdym pedagogicznym przedsięwzięciu zorientowanym na osiągnięcie sukcesu w nauczaniu. Dlatego też między innymi Petar Jandrič wyraża to przekonanie mówiąc, że fenomen post-prawdy kształtować może w odpowiedzi swoistą krytyczną 
pedagogikę zaufania ${ }^{11}$. Pedagogika zaufania wychodzi nie tylko naprzeciw rozwarstwieniu pojęcia prawdy w omawianym kontekście, lecz również dostarcza pewnych narzędzi zezwalających zmierzyć się z oferowanym przez fałszywy świat zachęcająco prostym rozwiązaniom wysoce skomplikowanych problemów. Rzecz jasna, pedagogika oparta na imperatywie prawdy wykazuje w tej mierze wysoki stopień idealizmu, którego zderzenie z realiami politycznymi i społecznymi może wypadać na niekorzyść projektu implementacji tego pojęcia w procesach nauczania. Jandrič przywołując jednak w swej argumentacji pojęcie zaufania, znacząco poszerza dyskusję na temat roli post-prawdy w edukacji. Semantyczna bliskość prawdy i zaufania wyrażona jest bowiem poprzez zespolenie tych pojęć z edukacyjnym wysiłkiem na rzecz ich urzeczywistnienia, nawet w kondycji nie sprzyjającej tego typu działaniom. Konieczne staje się zatem bliższe przyjrzenie się problemowi prawdy w optyce kultury szkoły, w której zaufanie staje się kluczową wartością w możliwości efektywnego nauczania. Jej obecność niweluje bowiem szanse proliferacji wspomnianych przeze mnie na początku partykularyzmów, tak indywidualnych wyborów, jak i społecznego zaangażowania wychowanków.

W podobnym tonie wypowiada się także Dexter Da Silva, wskazując na znaczenie modelu pedagogiki zaufania. Uznaje on, że we współczesnym zglobalizowanym świecie prawdziwe zaufanie, w przeciwieństwie do oczekiwań, zależności, pewności, czy poczucia zobligowania, zajmuje jeszcze bardziej centralną rolę, aniżeli miało to miejsce w latach poprzednich ${ }^{12}$. Kluczowa rola, jaką przypisuje się obecnie problemowi zaufania jest, zdaniem brazylijskiego uczonego, wynikiem jego powszechnego deficytu. Brak zaufania objawia się w odniesieniu tak do instytucji, jak też w mikrospołecznym wymiarze relacji i interakcji. Uwagi te odpowiadają spostrzeżeniom poczynionym wcześniej przez Piotra Sztompkę, który kreśląc trajektorie geometrii zaufania zauważa, że zaufanie wiąże się także z kapitałem społecznym ${ }^{13}$. Kapitał społeczny staje się w tym przypadku zależny wobec sieci relacji wytwarzanych poprzez interakcje społeczne, rodząc bliskość więzi w tym sensie, iż skłonni jesteśmy w pewnych okolicznościach zaufać innym i wyrażanym przez nich twierdzeniom. Zakładamy zatem, iż pewne grupy społeczne posiadają na przykład większy poziom kapitału edukacyjnego i wiedzy w wybranych kwestiach. Jest to swoisty psychologiczny mechanizm wyparcia odpowiedzialności, dostrzeżony swego czasu przez Ericha Fromma jako niebezpieczny w swym wymiarze społecznym krok w stronę ucieczki od personalistycznie pojmowa-

${ }^{11}$ P. Jandrič, Post-truth and Critical Pedagogy of Trust, [w:] Post-Truth, Fake News. Viral Modernity and Higher Education, red. M.A. Peters, S. Rider Shannon, Singapore 2018, s. 101-111.

12 D. Da Silva, Towards a Pedagogy of Trust, Keisen University Bulletin, 2009, s. 88.

${ }^{13}$ P. Sztompka, Zaufanie: fundament społeczeństwa, Kraków 2007. 
nej wolności ${ }^{14}$. Da Silva dostrzega jednak ważną rolę, jaką w zniwelowaniu opisanego wyżej procesu pełni edukacja. Forma, jaką edukacja musi przyjąć, aby osiągnąć założony cel, winna odwoływać się do zbiorowego wysiłku. Jedną z postaci wskazanego przez Da Silvę przedsięwzięcia jest edukacja kooperatywna - doskonale znany między innymi w krajach azjatyckich, takich jak na przykład Japonia zespół metod dydaktycznych wspomagających proces uczenia się. Jedną z form tego zespołu metod jest nauczanie „brzęczykowe" (ang. buzz learning), w którym w celu realizacji zadania pedagogicznego uczniowie muszą autentycznie zaufać nauczycielowi, a on zaś zmuszony jest im pomóc $w$ tym procesie. Skuteczna edukacja kooperatywna, realizowana $\mathrm{w}$ tej czy innej postaci, wymaga jednak spełniania kilku podstawowych warunków. Należą do nich: 1) pozytywna współzależność; 2) indywidualna odpowiedzialność; 3) bezpośrednia interakcja pomiędzy uczestnikami; 4) kompetencje społeczne; 5) grupowe przepracowanie omawianych problemów ${ }^{15}$. Zespolenie tych warunków w trakcie procesu nauczania pozwala na osiągnięcie wymiernych korzyści edukacyjnych nie tylko dla wszystkich uczestników procesu kształcenia, lecz skutkuje także zwiększeniem poziomu zaufania na innych płaszczyznach. Warto wspomnieć, że jedną z korzyści osiąganych dzięki zastosowaniu edukacji kooperatywnej jest również zniwelowanie relacji autorytarnie rozumianej władzy, co z kolei wynika z zależności, wskazanej nieco wcześniej przez Stuarta Reesa w jego modelu, wahadła władzy ${ }^{16}$. Argument ten uderza otwarcie w oparty na post-prawdzie wzorzec edukacyjny, który odnaleźć możemy obecnie w polskim systemie kształcenia, ale też wielu innych. Model ten bazuje bowiem na założeniu, iż pewne istniejące relacje władzy muszą pozostać nienaruszone, nawet jeśli wymagałoby to podważenia twierdzeń naukowych, których zasadność merytoryczna nie pozostawia cienia wątpliwości, że struktury te nie tylko są bezpodstawne, ale też szkodliwie dla całości systemu społecznego. Rodzi się w ten sposób swoisty stan post-edukacyjnej inwersji celów i zadań, w której szkoły zaczynają pełnić w pierwszej kolejności rolę politycznego narzędzia utrzymania porządku władzy, rozprzęgając przy tym poczucie wspólnotowej tożsamości i sprawczości podmiotu.

Czym byłaby w powyższym świetle post-edukacja? Tym mianem określić możemy te postaci kształcenia w ramach instytucji edukacyjnych, jak i innych, mniej sformalizowanych sposobów przekazywania wiedzy, które nie wymagają racjonalnych podstaw wypływających z ustaleń o charakterze analityczno-indukcyjnym, lecz odwołują się raczej do emocji, sentymentów i bazują na osadzonych $\mathrm{w}$ dyskursach medialnych i politycznych przekona-

${ }^{14}$ E. Fromm, Ucieczka od wolności, Warszawa 2008.

${ }^{15}$ D. Da Silva, Towards a Pedagogy of Trust, Keisen University Bulletin, 2009, s. 89.

${ }^{16}$ S. Rees, Passion for peace: Exercising power creatively, Sydney 2003. 
niach, stereotypowych wyobrażeniach, czy fałszywych twierdzeniach. Post-edukacja nie tylko w takim układzie korzysta z popularności antyintelektualnych postulatów, ale są one dla jej trwania niezbędne. Takie pojmowanie post-edukacji implikuje jeszcze jeden ważny krok na drodze jej identyfikacji. Jest nim wyeksponowanie złożonego zespołu czynników kulturowych regulujących irracjonalny, wydawałoby się, mechanizm wyparcia tez o podstawach zakorzenionych w faktach. Kulturowo określone zostają bowiem drogi, jakimi rzeczywistość zostaje zarówno zinternalizowana, jak i wyrażone zostają pewne przekonania na temat tego, jak winna ona wyglądać w subiektywnym przekonaniu. Waga, jaką przywiązuje do aspektu subiektywnego i emocjonalnego populizm polityczny oraz ruchy reprezentujące ten typ politycznej retoryki z pewnością pozostaje kwestią do dyskusji. Kluczowym problemem w tym kontekście jest jednak stopien, w jakim ruchy te realnie wpływają na transformację rzeczywistości politycznej i społecznej w takich krajach, jak na przykład Polska. Jest to pytanie o tyle ważne, że transformacja współczesnej polskiej kultury politycznej pozostaje w bezpośrednim sprzężeniu ze zmianami w poszczególnych obszarach sfery życia publicznego. Edukacja i szkolnictwo w Polsce, będąc jedną z takich sfer, jest też w orbicie zainteresowania polityki jako jeden z obszarów, w którym formowana jest zbiorowa tożsamość i kształtowane są predyspozycje do uczestnictwa w życiu wspólnotowym. Postawy obywatelskie, zorientowanie na cele wyższego rzędu i kształtowanie perspektyw długofalowych oraz ponadjednostkowych przeciwstawione zostają jednostkowemu interesowi oraz ekonomizacji wysiłku. Staje się ona nowym celem edukacyjnym, zarówno w sensie partykularnych strategii uczenia się, kultury organizacyjnej szkół i całego polskiego systemu kształcenia, jak i wpisany zostaje w system parametryzacyjnej oceny pracowników akademickich regulujący ich naukowe wybory. Oczywistym skutkiem tego kierunku zmian w rzeczywistości edukacyjnej jest instrumentalizacja podmiotu kształcenia, ale również wszystkich jednostek zaangażowanych w system kształcenia na każdym z poziomów ${ }^{17}$. Proces ten nie jest rzecz jasna jedynie częścią specyfiki polskiego systemu nauczania i szkolnych realiów, lecz stanowi zjawisko widoczne także w innych krajach.

Państwa skandynawskie, w których systemy edukacji wykazywały do niedawna wysoki poziom efektywności kształcenia wydają się obecnie również dotknięte przez post-edukację, jak wiele innych lokalnych systemów. Problem ten dostrzegają między innymi Magnus Henrekson i Johan Wennström, stawiając tezę, iż szwedzkie szkoły silnie zorientowane są na paradygmat społecznego konstruktywizmu, a przez to też możemy dostrzec

${ }_{17}$ M.A. Peters, S. Rider i in., Post-Truth, Fake News. Viral Modernity and Higher Education, Singapore 2018, s. 3. 
w szwedzkim systemie nauczania stały spadek osiąganych przez uczniów wyników ${ }^{18}$. Jest to dość zaskakujące twierdzenie, zważywszy, że Szwecja jest krajem, który od lat wydaje się pozostawać w czołówce państw cechujących się równie wysokim poziomem rozwoju gospodarczego, co edukacji. Skandynawski wzorzec sukcesu edukacyjnego uformowany został w kontekście powojennego boomu industrialnego, gdzie nienaruszona działaniami wojennymi infrastruktura przemysłowa i rozwijająca się szybko gospodarka wymagała wysoce wykwalifikowanych kadr. To w latach 50. i 60. XX wieku szwedzki system szkolnictwa zaczął ewoluować zgodnie z wytycznymi konstruktywistycznymi. Punktem kulminacyjnym było natomiast wprowadzenie w roku 1994 nowego narodowego programu nauczania, poprzez który nastąpiła wyraźna decentralizacja systemu szkolnictwa podstawowego i średniego oraz wprowadzono vouchery edukacyjne, otwierając tym samym drogę do postępującej prywatyzacji sektora edukacyjnego. Stan ten wzmocniły następnie zmiany z roku 2011. Z czasem widoczne stały się, wynikające z powyższych zmian, problemy trapiące szwedzkie szkoły, jak na przykład bardzo wysoki stopień absencji szkolnej wśród uczniów, jak również rosnące problemy natury psychologicznej, gdzie stany lękowe i depresja pośród młodych ludzi stały się poważnym wyzwaniem dla tamtejszego systemu opieki zdrowotnej ${ }^{19}$. Wprowadzenie logiki ekonomii w sferze legislacyjnej i organizacyjnej przyniosło natomiast ten efekt, iż akceptowalne stały się wypowiedzi negujące naukowe ustalenia, pod warunkiem, iż przynosiły one nominalny lub bardziej wizerunkowy zysk wybranym instytucjom edukacyjnym. Zdaniem szwedzkich uczonych, kłopoty dotykające obecnie szwedzkie szkoły wynikają z przyjętej tam wizji edukacji, w której umniejszona zostaje rola nauczycieli na rzecz imperatywu bezwzględnego zachowania subiektywnego dobrostanu ucznia i wszelkich związanym z tym warunków. Negatywny wpływ konstruktywizmu upatrują oni w obniżeniu morale zawodowego nauczycieli, jak i statusu wiedzy jako takiej ${ }^{20}$.

Spoglądając na post-edukacyjny pejzaż i cechującego go antyintelektualne fenomeny, zarówno w ich lokalnym, jak i globalnym wymiarze, nietrudno odnieść wrażenie, że pole edukacji jest obecnie trapione przez liczne paradygmatyczne i instytucjonalne stany kryzysowe. Polski system kształcenia nie stanowi w tej kwestii wyjątku, a ogólnopolski strajk nauczycieli udowodnił, jak dalece sięga ów kryzys oraz jak kształtuje się obecny stan systemu szkolnictwa. Rozpatrując przyczyny tego stanu, możemy jednak zwrócić się w stronę szerszego i dostrzegalnego obecnie frontu kulturowego, u podstaw

${ }^{18}$ M. Henrekson Magnus, J. Wennström, "Post-Truth" Schooling and Marketized Education: Explaining the Decline in Sweden's School Quality, IFN Working Paper, 2018, 1228, s. 2.

19 Tamże, s. 8.

${ }^{20}$ Tamże, s. 37. 
którego leży zjawisko poszerzania horyzontu post-prawdy i postaw antyintelektualnych. Idąca za tym negacja edukacyjnych ideałów wywiera natomiast istotny wpływ na to, jak formowane są nowe kierunki zmiany w zakresie filozofii kształcenia, stojącej za praktyką edukacyjną dającą się zaobserwować w rzeczywistości szkolnej. Rodzi to zaś dalsze pytania na temat przyszłości polskiej szkoły w szerszym kontekście transformacji społeczeństwa polskiego, w tym budowanych w procesie kształcenia postaw obywatelskich i poczucia odpowiedzialności za wspólną przyszłość. Warto także zaznaczyć, że pytanie to nabiera szczególnego znaczenia $\mathrm{w}$ obliczu niesionych przez post-prawdę wyzwań wobec tradycyjnie pojmowanej roli szkoły jako narzędzia, poprzez które postawy te zostają uwewnętrznione i upowszechnione.

\section{BIBLIOGRAFIA}

Baginni J., A Short History of Truth. Consolations ofr the Post-Truth World, London 2018.

Da Silva D., Towards a Pedagogy of Trust, Keisen University Bulletin, 2009.

Fromm E., Ucieczka od wolności, Warszawa 2008.

Gdula M., Dobra zmiana w Miastku. Neoautorytaryzm w polskiej polityce z perspektywy matego miasta, Warszawa 2017.

Gilchrist A., Post-truth: an outline review of the issues and what is being done to combat it, Ibersid 2018, 12-2.

Henrekson M., Wennström J., "Post-Truth" Schooling and Marketized Education: Explaining the Decline in Sweden's School Quality, IFN Working Paper, 2018, 1228.

Horkheimer M., Społeczna funkcja filozofii, Warszawa 1987.

Jandrič P., Post-truth and Critical Pedagogy of Trust, Peters, New York 2018.

Micheal A., Rider S. et al., Post Truth, Fake News. Viral Modernity and Higher Education, Singapore 2018.

Tesich S., A Government of Lies, The Nation, 1992, 254, 1.

Keyes R., The Post-Truth Era: Dishonesty and Deception in Contemporary Life, New York 2004.

Peters M.A., Rider S. et al., Post-Truth, Fake News. Viral Modernity and Higher Education, Singapore 2018.

Rees S., Passion for peace: Exercising power creatively, Sydney 2003.

Speed E., Mannion R., The Rise of Post-truth Populism in Pluralist Liberal Democracies: Challenges for Health Policy, International Journal Health Policy Management, 2017, 6(5).

Sztompka P., Zaufanie: fundament społeczeństwa, Kraków 2007.

Worthen K.J., The Pursuit of All Truth, Brigham Young University Speeches 2017. 